\title{
The Influence of Social Factors, Trust, Website Quality, and Perceived Risk on Repurchase Intention in E-Commerce
}

Submitted Date :

25 August 2021

Accepted Date :

18 October 2021
Axellino Tegar Hieronanda Faculty of Economic and Business, Universitas Kristen Satya Wacana nanda.tegar@gmail.com

Albert Kriestian Novi Adhi Nugraha* Faculty of Economic and Business, Universitas Kristen Satya Wacana albert.kriestian@uksw.edu

\section{Suggested Citation:}

Lal, P. (2017). Analyzing determinants influencing an individual's intention to use social commerce website. Future Business Journal, 3(1), 70-85. https://doi.org/10.1016/j.fbj.2017.02.001

Abstract:

In recent years, internet shopping has become a culture to fulfill their needs, goods, and services. Many users of ecommerce services can be a chance to develop new business models, although the users may experience a certain amount of risk associated with their purchase. The purpose of this study is to examine (from a consumer perspective) the main aspects that affecting consumer's repurchase intentions through an e-commerce website. Specifically, the current study investigated the impact of social factors, trust, website quality, and perceived risk on repurchase intentions at Shopee ecommerce by using structural equation model analysis. The population is individual Shopee users in Indonesia. A sample consists of 238 respondents was obtained using the purposive sampling technique. The results indicate that social factors, trust, and website quality do not affect repurchase intentions in e-commerce. In contrast, risk affects repurchase intentions in e-commerce.

Keywords: Perceived Risk; Repurchase Intention; Social Factors; Trust; Website Quality

JEL Classification: M31

${ }^{*}$ Corresponding Author 


\section{Research Background}

Industrial Revolution 4.0 is characterized as a change in the production system that utilizes manual and digital technological advances. Industrial Revolution 4.0 aims to facilitate the production process that is supported by technological developments globally. The Industrial Revolution 4.0 has influenced business development in Indonesia, both in the private and public sectors. Besides, the Industrial Revolution 4.0 also influenced various aspects such as politics, law, culture, and many more. Since the transition to the global digital network, the internet allows business organizations to meet domestic and international demand needs through e-commerce (Lim et al., 2016). Internet shopping has become a common way to satisfy the need for goods and services (Lim \& Dubinsky, 2004). Experian (2018) stated that e-commerce users in Indonesia reached $75 \%$ of the total number of respondents who use digital services in 2018, both domestic and international e-commerce users. However, this was also followed by a high number of cases of fraud in e-commerce transactions. According to Experian (2018), In Indonesia, 25\% of respondents have experienced fraud when making online transactions in ecommerce. Many e-commerce users can be a new opportunity for society to explore various new models of doing business. However, there is an issue of risk associated with the implementation, particularly in the perspective of its users, where 25 percent of respondents have experienced fraud when making online transactions, researchers want to know the reasons why people choose online transactions even though the risk of fraud is quite high.

The current study differs compared with previous ones in the choice of sample. For instance, previous studies used samples in developed countries, such as the United States of America (Mandilas et al., 2013). And also use the sample in India (Lal, 2017). The current study chose individual e-commerce users in Indonesia as a sample. Based on previous research by Lal (2017); Y. J. Lim et al. (2016), the researcher used social factors, trust, and website quality as the independent variables and e-commerce as the dependent variable.

Furthermore, the current study posits additional factors, namely perceived risk, as an independent variable taken from research done by (Mandilas et al., 2013). The subject of a survey held for the current study was Shopee users. Shopee was established in 2015 in Singapore, and then its operation expanded to various countries such as Malaysia, Vietnam, Taiwan, the Philippines, Thailand, and Indonesia. Shopee stands under the auspices of the Singapore-based SEA Group, which was established in 2009 by Forrest Li (Saputro, 2019). Therefore, due to its international operations, the current study chose Shopee as the study object.

Consumer behavior theory is a theory that explains how an individual, group, or organization chooses, uses, or buys an item or service to meet their needs, whether they are needs or wants. Consumer behavior combines several ideas from existing sciences, such as psychology, biology, chemistry, and economics (Friesner, 2014). Marketers expect that by understanding consumer behavior, which is why consumers buy or choose an item and service, they can determine which products they need based on their understanding of consumer need and want.

Consumer behavior comprises two parts, rational behavior and irrational behavior. Rational behavior is where consumers consume goods or services because the product serves mostly functional benefits accompanied by consumers' ability to buy the product. Consumers try to look for optimum satisfaction to fulfill their needs. Irrational behavior is where consumers mostly look for emotional benefit from the purchase of the product. They consume goods or services based on their wants for prestige, and sometimes they spend more money than they can afford. According to Dominguez (2018), consumer behavior is affected by several aspects such as distribution patterns of the products, promotion, packaging, price, and product design as marketing aspects and from individual factors, such as their taste, age, gender, education level, and income level; environmental factors, such as social status, then the influence of family, groups, and friends; cultural factors, such as religion, and caste; psychological factors, such as motivation in buying products, and perceptions of these products.

Social factors have a significant function in using e-commerce to transaction goods or services online. Social factors include reference groups, families, social roles, and social status (Cetină et al., 2012). The effect of social factors on intention to utilize e-commerce platforms has been studied by previous scholars (Cetină et al., 2012; Lal, 2017). Traditionally, studies on social elements focused more on social influence, as to how a person's attitude or the opinions of others can influence individual decision making (Venkatesh \& Morris, 2000). Personal behavior was affected by social aspects such as social commitment and support that stimulate interaction and association between its affiliate. It also assists people in developing close links with other participants in the group, which can lead to personal dedication to the organization (Liang et al., 2011). According to Lal (2017) Informational Support and Community Commitments have been recognized as social factors. Informational 
support can be expressed in advice, recommendations, or experience when using a product. These can help others to make decisions. According to Savolainen (2015), three informational support in the online discussion group environment includes providing factual data, recommending, and giving personal opinions.

In terms of e-commerce, individuals may have similar knowledge or beliefs about purchasing goods, distribution time, features of the goods, experience using the product, etc. In addition, another critical factor is Community Commitment. Based on Reis, Sprecher, \& Agnew (2013), commitment is defined as a person willing to continue in a series of actions. Previous research has shown that a higher engagement stage to online communities will guide more cooperation by an entity in the organization (Bateman et al., 2011). Engagement represents the ability of individuals to keep track of activities that occur in online communities and stay updates within growing online communities. In terms of e-commerce, the platform allows people to share their experiences of purchase or consumption. Suppose anyone discovers an online community with the same interests as theirs, and they can appreciate recommendations or opinions valued by other people. In that case, it will create a sense of ownership. If this happens, then the individual wants to be part of the community and become a permanent member for an extended period.

Customers are less likely to finish their transaction if they doubt the website or platform they use to shop (Chang \& Chen, 2008). The analyst studied trust to determine the effect of individual intention to utilize ecommerce for shopping (M. J. Kim et al., 2011; Lal, 2017). In terms of e-commerce, people frequently ask for assistance from social networks and people they can rely on for accurate insight about their experiences in buying products or utilize any available services. (Chen \& Shen, 2015). Trust toward members is categorized as a willingness of a person to rely on views, opinions, and advice from another person within the social trading organization (Chen \& Shen, 2015). In e-commerce, trust toward members is seen in the way people interact and are willing to support each other if a problem arises when someone wants to make a decision. In addition, a member will be trusted when the available information is categorized as appropriate for people to decide.

Furthermore, another dimension of trust is trust toward the community. Based on Lu, Zhao, \& Wang (2010), trust toward the community shows the individual's opinion on the online communities as competent and trustworthy online platforms to provide the best services in e-commerce. In terms of e-commerce, trust toward community need to be evaluated for providers of online e-commerce platforms where its ability to meet the expectations of individuals from the online communities, as those aspects could affecting personal trust in the online communities (Gefan et al., 2003). Thus, if a person has a positive understanding of the online community, the online community can persuade that individual to use e-commerce.

Based on Lal (2017), Website quality has a vital role in using an e-commerce platform or website. The impact of website quality on individual intention to utilize e-commerce platforms has been studied by researchers (Lal, 2017; Ye et al., 2016). In terms of e-commerce, social interaction has a vital role for individuals when they use e-commerce. Social interaction encourages the need for the website's guidance, which holds a major function because it affects someone's efforts to operate the platforms (Ye et al., 2016). Being able to control all forms of characteristic and functions support individuals to use the media in meeting their goals to gather information, communicate, and collaborate. Hence, e-commerce websites need to be designed to use the functions and features with no hassle. Subsequently, service quality also has an important role. Based on Liang et al. (2011),-service quality is defined as "the degree to which a user evaluates supports and services delivered by the service provider via the Website." In terms of e-commerce, service quality is assessed by how quickly customer care resolves customer questions. Responsiveness is relevant, especially when a user who does not understand technology faces technical issues. The customer service person can solve the problem without making the users feel upset about technical issues and complex processes.

A critical factor in using e-commerce is perceived risk. Mandilas et al. (2013) explained that perceived risk is described as "the extent for a consumer's belief about the potential uncertain negative outcomes from the online transaction." Tsiakis (2012) categorized six perceived risks: performance risk, social risk, financial risk, psychological risk, physical risk, and time risk. In online shopping, various categories of perceived risk are considered essential: financial risk, information, and product risk (Bhatnagar et al., 2000). Consumers usually feel uncertain when making online transactions because they perceive a higher risk for online shopping than traditional shopping (Mandilas et al., 2013). Risk draws attention and may discourage consumers from buying 
products online (Kim et al., 2008). Therefore, the previous study showed that perceived risk negatively affected consumer decisions (Fortes \& Rita, 2016; Li et al., 2011; Mandilas et al., 2013).

Assuming that e-commerce will be a fruitful topic for future research in economics, as well as in the fields of consumer behavior, marketing, and information systems, the objective of this research are to analyze the influence of social factors, trust, website quality and perceived risk on repurchase intention in e-commerce. From the consumers ' perspective, the research aims to analyze the main factors that influence the repurchase intention of an individual's decision to use e-commerce websites, especially in Indonesia

\section{Research Method}

This study is categorized as an explanatory study. The purpose of study research is to boost a researcher's knowledge on a particular subject and explain the effect of some predictors toward the dependent variable (Consultores, 2020). Explanatory research allows the researchers to explain how and why something might occur. The sampling technique in the current study applied purposive sampling. The respondent criteria in the present study are individuals who have used Shopee as their choice of e-commerce platforms in Indonesia. Based on Roscoe (1975), the suitable sample size for a study is among 30 to 500 samples. Therefore, following the guidelines provided by Roscoe, the sample size for this study is 200 respondents. The research process consists of several stages: data measurement or research instrument development, data collection, data validation, and reliability test, and data analysis. The latter part Further details on the research process are presented as follows: The proposed model consists of four independent variables: social factors, trust, website quality, perceived risk, and one dependent variable (i.e., repurchase intention in e-commerce).

Table 1. Data Measurement

\begin{tabular}{|c|c|c|c|c|}
\hline Variable & Scales & Items & & References \\
\hline \multirow[t]{2}{*}{ Social Factors } & $\begin{array}{l}\text { Informational } \\
\text { Support }\end{array}$ & $\begin{array}{l}\text { When I use X, some people will offer advice when I } \\
\text { need help } \\
\text { When I encounter a problem or difficulty, some } \\
\text { people in X will give me information to help me } \\
\text { solve the problem. }\end{array}$ & $\begin{array}{l}\text { SosFac1 } \\
\text { SosFac2 }\end{array}$ & $\begin{array}{l}\text { Chen \& Shen, } \\
\text { (2015); Liang et } \\
\text { al., (2011) }\end{array}$ \\
\hline & $\begin{array}{l}\text { Community } \\
\text { Commitment }\end{array}$ & $\begin{array}{l}\text { I feel a solid connection to } X \text {. } \\
\text { I feel a sense of belonging toward the } X \text {. } \\
\text { I feel like become a part of the group at } X \text {. }\end{array}$ & $\begin{array}{l}\text { SosFac3 } \\
\text { SosFac4 } \\
\text { SosFac5 }\end{array}$ & $\begin{array}{l}\text { Bateman et al., } \\
\text { (2011); Chen \& } \\
\text { Shen, (2015) }\end{array}$ \\
\hline \multirow[t]{2}{*}{ Trust } & $\begin{array}{l}\text { Trust Toward } \\
\text { Community }\end{array}$ & $\begin{array}{l}\text { The performance of } X \text { always meets my } \\
\text { expectations. } \\
X \text { can be considered a good e-commerce } \\
\text { site/platform. } \\
X \text { is a reliable e-commerce site/platform. }\end{array}$ & $\begin{array}{l}\text { Trust1 } \\
\text { Trust2 }\end{array}$ & $\begin{array}{l}\text { Chen \& Shen, } \\
\text { (2015); Liang et } \\
\text { al., (2011) }\end{array}$ \\
\hline & $\begin{array}{l}\text { Trust Toward } \\
\text { Members }\end{array}$ & $\begin{array}{l}\text { Members in } X \text { always keep their promises. } \\
\text { Members in } X X \text { are truthful in dealing with each } \\
\text { other. }\end{array}$ & $\begin{array}{l}\text { Trust4 } \\
\text { Trust5 }\end{array}$ & $\begin{array}{l}\text { (Chen \& Shen, } \\
\text { 2015) }\end{array}$ \\
\hline \multirow[b]{2}{*}{$\begin{array}{l}\text { Website } \\
\text { Quality }\end{array}$} & $\begin{array}{l}\text { Ease of } \\
\text { Navigation }\end{array}$ & $\begin{array}{l}\text { Platform } X \text { has a function that allows users to get } \\
\text { information quickly and accurately. } \\
\text { Platform } X \text { provides a friendly user interface. } \\
\text { Platform } X \text { makes it easy to provide information to } \\
\text { us. }\end{array}$ & $\begin{array}{l}\text { WebQua1 } \\
\text { WebQua2 } \\
\text { WebQua3 }\end{array}$ & $\begin{array}{l}\text { (Liang et al., } \\
\text { 2011) }\end{array}$ \\
\hline & Service Quality & $\begin{array}{l}\text { Platform X provides a reliable service. } \\
\text { Platform X gives prompt service to users. } \\
\text { Platform X pays attention to the user's individual } \\
\text { needs. } \\
\text { Platform X understands the specific needs of its } \\
\text { users. }\end{array}$ & $\begin{array}{l}\text { WebQua4 } \\
\text { WebQua5 } \\
\text { WebQua6 } \\
\text { WebQua7 }\end{array}$ & $\begin{array}{l}\text { (Liang et al., } \\
\text { 2011) }\end{array}$ \\
\hline \multirow{3}{*}{ Perceived Risk } & Financial Risk & $\begin{array}{l}\text { Purchasing items online is risky. } \\
\text { Shopping online is risky. } \\
\text { It is riskier to shop online than offline for a product }\end{array}$ & $\begin{array}{l}\text { Risk1 } \\
\text { Risk2 } \\
\text { Risk3 }\end{array}$ & $\begin{array}{l}\text { (Schlosser } \\
\text { al., 2006) }\end{array}$ \\
\hline & $\begin{array}{l}\text { Information } \\
\text { Risk }\end{array}$ & $\begin{array}{l}\text { Providing debit/credit card information online is } \\
\text { risky. }\end{array}$ & Risk4 & $\begin{array}{l}\text { (Schlosser } \\
\text { al., 2006) }\end{array}$ \\
\hline & & $\begin{array}{l}\text { Providing personal information (i.e., social security } \\
\text { number and mother's maiden name) online is risky. } \\
\text { Providing my email address and phone number }\end{array}$ & Risk5 & \\
\hline
\end{tabular}




\begin{tabular}{|c|c|c|c|c|}
\hline Variable & Scales & Items & & References \\
\hline \multirow{7}{*}{$\begin{array}{c}\text { Repurchase } \\
\text { Intention in E- } \\
\text { commerce }\end{array}$} & & online is risky. & & \multirow{7}{*}{ (Lal, 2017) } \\
\hline & & Registering online is risky. & Risk7 & \\
\hline & & I am willing to share my experiences and & Replnt1 & \\
\hline & & $\begin{array}{l}\text { suggestions when my friends in } \mathrm{X} \text { want my advice } \\
\text { on buying something in } \mathrm{X} \text {. }\end{array}$ & & \\
\hline & & $\begin{array}{l}\text { There are positive recommendations for products } \\
\text { on the } X \text {. }\end{array}$ & Replnt2 & \\
\hline & & $\begin{array}{l}\text { There have been good experiences in the past } \\
\text { when I purchased products at } X \text {. }\end{array}$ & RepInt3 & \\
\hline & & $\begin{array}{l}\text { I am willing to repurchase products in the future } \\
\text { through } X \text {. }\end{array}$ & Replnt4 & \\
\hline
\end{tabular}

Source: Literature Review Processed (2021)

Result

This research uses primary data as the data source, obtained by distributing online questionnaires held through Google Form. The data collection period was from June 16, 2021, to June 30, 2021, with 238 respondents. Table 3 presents the profile of respondents as follows:

Table 2. Demographic Profile

\begin{tabular}{|c|c|c|c|c|c|}
\hline No & Category & Sub-Category & Frequencies & Percentage & Total \\
\hline \multirow{4}{*}{1} & & Male & 106 & $44.5 \%$ & \multirow{4}{*}{238} \\
\hline & Gender & Female & 132 & $55.5 \%$ & \\
\hline & & $19-24$ & 165 & $69.3 \%$ & \\
\hline & & $25-30$ & 32 & $13.4 \%$ & \\
\hline \multirow[t]{4}{*}{2} & Age & $31-36$ & 11 & $4.6 \%$ & \multirow[t]{4}{*}{238} \\
\hline & & $37-42$ & 13 & $5.5 \%$ & \\
\hline & & $43-48$ & 1 & $0.4 \%$ & \\
\hline & & Master Degree & 5 & $2.1 \%$ & \\
\hline \multirow{6}{*}{3} & & Bachelor Degree & 127 & $53.4 \%$ & \multirow{6}{*}{238} \\
\hline & Education Level & Senior High School & 102 & $42.9 \%$ & \\
\hline & & Junior High School & 4 & $1.7 \%$ & \\
\hline & & Unemployment & 5 & $2.1 \%$ & \\
\hline & & Housewife & 2 & $0.8 \%$ & \\
\hline & & College Student & 123 & $51.7 \%$ & \\
\hline \multirow[t]{4}{*}{4} & Job & Makeup Artist & 2 & $0.8 \%$ & \multirow[t]{4}{*}{238} \\
\hline & & Private Employee & 60 & $25.2 \%$ & \\
\hline & & Civil Servant & 18 & $7.6 \%$ & \\
\hline & & Entrepreneur & 28 & $11.8 \%$ & \\
\hline
\end{tabular}

Source: Primary Data (2021)

Based on Table 3, female respondents were the majority of total respondents, with 132 respondents or $55.5 \%$. The remaining 106 respondents, or $44.5 \%$, were identified as male respondents. Most respondents were between ages 19 and 24 years $(69.3 \%)$, and the minor proportion was 43 to 48 years $(0.4 \%)$. Furthermore, most respondents based on educational backgrounds were Bachelor Degree with 127 respondents or $53.4 \%$, while for Junior High School educational backgrounds it has the least number 1.7\%. Lastly, it can be seen that students were the majority of respondents, with a total of 123 respondents or $51.7 \%$. At the same time, Makeup Artist and Housewife were minor numbers, that is, two respondents for each job with a presentation of $0.8 \%$ each.

The validity test in this research was carried out by using IBM SPSS 23.0 software. The validity test criteria are that the Corrected Item - Total Correlation value must be higher than the value of $r$ table at the significant level (a) 0.05 , which is $>0.138$. If the value of Corrected Item - Total Correlation is greater than the specified $r$ table, it can justify that the indicator passes the validity test (Ghozali, 2016). Furthermore, the reliability 
test will be carried out using IBM SPSS 23.0 software. The criteria for the item reliability test are Cronbach's alpha value, which is at least 0.6 .

Table 2. Validity and Reliability Test Result

\begin{tabular}{|c|c|c|c|c|}
\hline Indicator & Cronbach's Alpha & Interpretation & Item & Corrected Item - Total Correlation \\
\hline \multirow{3}{*}{ SosFacA } & \multirow{3}{*}{0.642} & \multirow{3}{*}{ Usable } & SosFac1 & 0.590 \\
\hline & & & SosFac2 & 0.466 \\
\hline & & & SosFac3 & 0.553 \\
\hline \multirow[t]{3}{*}{ SosFacB } & \multirow[t]{3}{*}{0.866} & \multirow[t]{3}{*}{ Ideal } & SosFac4 & 0.558 \\
\hline & & & SosFac5 & 0.584 \\
\hline & & & Trust1 & 0.581 \\
\hline \multirow[t]{2}{*}{ TrustA } & \multirow[t]{2}{*}{0.683} & \multirow[t]{2}{*}{ Usable } & Trust2 & 0.549 \\
\hline & & & Trust3 & 0.514 \\
\hline \multirow{3}{*}{ TrustB } & \multirow{3}{*}{0.675} & \multirow{3}{*}{ Usable } & Trust4 & 0.511 \\
\hline & & & Trust5 & 0.536 \\
\hline & & & WebQua1 & 0.588 \\
\hline \multirow[t]{4}{*}{ WebQuaA } & \multirow[t]{3}{*}{0.712} & \multirow[t]{3}{*}{ Ideal } & WebQua2 & 0.578 \\
\hline & & & WebQua3 & 0.515 \\
\hline & & & WebQua4 & 0.573 \\
\hline & \multirow{4}{*}{0.809} & \multirow{4}{*}{ Ideal } & WebQua5 & 0.614 \\
\hline \multirow{3}{*}{ WebQuaB } & & & WebQua6 & 0.522 \\
\hline & & & WebQua7 & 0.550 \\
\hline & & & Risk 1 & 0.268 \\
\hline \multirow[t]{3}{*}{ RiskA } & \multirow[t]{3}{*}{0.681} & \multirow[t]{3}{*}{ Usable } & Risk 2 & 0.283 \\
\hline & & & Risk 3 & 0.344 \\
\hline & & & Risk 4 & 0.161 \\
\hline \multirow{4}{*}{ RiskB } & \multirow{4}{*}{0.751} & \multirow{3}{*}{ Ideal } & Risk 5 & 0.167 \\
\hline & & & Risk 6 & 0.325 \\
\hline & & & Risk 7 & 0.275 \\
\hline & & & Replnt1 & 0.489 \\
\hline \multirow{3}{*}{ Replnt } & \multirow{3}{*}{0.704} & \multirow{3}{*}{ Ideal } & Replnt2 & 0.455 \\
\hline & & & Replnt3 & 0.527 \\
\hline & & & RepInt4 & 0.514 \\
\hline
\end{tabular}

Source: Primary Data (2021)

Table 4 shows that all items are valid, with the lowest value of Corrected Item - Total Correlation for the item Risk4 (0.161). Furthermore, Table 3 also presents the outcomes of the reliability assessment, most of which show the excellent Cronbach's alpha value for several variables. However, some variables show low values for SosFacA, TrustA, TrustB, and Risk. However, following George \& Mallery (2016), all those three constructs are still considered reliable.

Normality test was carried out by using IBM AMOS 22.0 software. The procedure was to compare the critical ratio (CR) value in the assessment of normality with a critical value of \pm 2.56 . If $C R$ value is greater than the predetermined critical ratio value, then data do not follow a pattern of univariate data normality. Following the same rule of thumb, the value of $\mathrm{CR}$ as a basis to assess multivariate data normality can be evaluated in the last line from Table 5 (Ghozali, 2014).

Table 3. Normality Test Result

\begin{tabular}{ccccccc} 
Variable & min & max & skew & c.r. & kurtosis & c.r. \\
\hline Replnt1 & 2,000 & 5,000 &,- 901 & $-5,674$ &, 494 & 1,556 \\
Replnt2 & 1,000 & 5,000 & $-1,162$ & $-7,320$ & 2,940 & 9,259 \\
Replnt3 & 2,000 & 5,000 &,- 828 & $-5,213$ &, 798 & 2,513 \\
Replnt4 & 1,000 & 5,000 & $-1,460$ & $-9,196$ & 4,641 & 14,614 \\
Risk1 & 2,000 & 5,000 &,- 670 & $-4,221$ &, 045 &, 141 \\
Risk2 & 1,000 & 5,000 &,- 962 & $-6,061$ & 1,578 & 4,969 \\
Risk3 & 1,000 & 5,000 & $-1,435$ & $-9,037$ & 2,774 & 8,737 \\
Risk4 & 2,000 & 5,000 &,- 493 & $-3,107$ &,- 243 &,- 765 \\
Risk5 & 2,000 & 5,000 &,- 507 & $-3,195$ &, 090 &, 282 \\
Risk6 & 1,000 & 5,000 & $-1,220$ & $-7,681$ & 1,964 & 6,184 \\
Risk7 & 1,000 & 5,000 &,- 634 & $-3,996$ &, 389 & 1,224
\end{tabular}




\begin{tabular}{ccccccc} 
Variable & min & max & skew & \multicolumn{1}{c}{ c.r. } & kurtosis & c.r. \\
\hline WebQua1 & 1,000 & 5,000 & $-1,369$ & $-8,621$ & 2,105 & 6,627 \\
WebQua2 & 1,000 & 5,000 & $-1,627$ & $-10,244$ & 4,082 & 12,856 \\
WebQua3 & 1,000 & 5,000 & $-1,036$ & $-6,524$ & 2,065 & 6,502 \\
WebQua4 & 1,000 & 5,000 & $-1,051$ & $-6,622$ & 2,382 & 7,500 \\
WebQua5 & 1,000 & 5,000 & $-1,108$ & $-6,981$ & 2,964 & 9,334 \\
WebQua6 & 1,000 & 5,000 &,- 942 & $-5,935$ & 1,690 & 5,322 \\
WebQua7 & 1,000 & 5,000 & $-1,323$ & $-8,332$ & 3,264 & 10,280 \\
Trust1 & 1,000 & 5,000 &,- 811 & $-5,105$ & 1,274 & 4,010 \\
Trust2 & 1,000 & 5,000 &,- 909 & $-5,724$ & 1,640 & 5,164 \\
Trust3 & 1,000 & 5,000 &,- 849 & $-5,349$ & 2,078 & 6,544 \\
Trust4 & 1,000 & 5,000 &,- 464 & $-2,922$ &, 688 & 2,166 \\
Trust5 & 1,000 & 5,000 &,- 431 & $-2,715$ &, 264 &, 831 \\
SosFac1 & 1,000 & 5,000 &,- 721 & $-4,539$ &, 714 & 2,248 \\
SosFac2 & 2,000 & 5,000 &,- 457 & $-2,876$ &, 008 &, 026 \\
SosFac3 & 1,000 & 5,000 &,- 592 & $-3,727$ &,- 184 &,- 580 \\
SosFac4 & 1,000 & 5,000 &,- 505 & $-3,181$ &,- 115 &,- 363 \\
SosFac5 & 1,000 & 5,000 &,- 631 & $-3,975$ &,- 015 &,- 046 \\
Multivariate & & & & & 135,329 & $\mathbf{2 5 , 4 6 8}$ \\
\hline
\end{tabular}

Source: Primary Data (2021)

Table 5 shows the outputs of the univariate normality assessment, and most of the data are normally distributed. While the multivariate value is 25,468 , this value is far above 2.56 , so the data does not meet the criteria for multivariate data normality.

As data do not meet the assumption of normality, the following procedure was to re-examine data using the maximum likelihood bootstrap technique with Bollen Stine estimation (Ferawati, 2010). The bootstrap method can be an alternative for Structural Equation Modelling (SEM) to overcome multivariate non-normal data. The bootstrap method does not have to meet a multivariate normal assumption as in the ML method. If the BollenStine $p$-value is less than $0.05(p<0.05)$, the model will be invalid or have to modify model to continue the research.

Table 4. Maximum Likelihood Bootstrap Result Initial

\section{Bollen-Stine Bootstrap (Default Model)}

The model fit better in 238 bootstrap samples.

It fit about equally well in 0 bootstrap samples.

It fit worse or failed to fit in 0 bootstrap samples.

Testing the null hypothesis that the model is correct, Bollen-Stine bootstrap $p=, 004$

Source: Primary Data (2021)

Based on Table 6 above, after the bootstrapping procedure, the results of the Bollen-Stine bootstrap probability are 0.004 . This value is significant at the significant level (a) 0.05 , so this research model is rejected. Based on the result, this research model must be modified to continue the research with the modified model and discard outlier data whose details were explained in the outlier test. A detailed explanation of the model modification was described in the Modification Index in the following discussion.

\section{Table 5. Maximum Likelihood Bootstrap Result Modified}

\section{Bollen-Stine Bootstrap (Default Model)}

The model fit better in 169 bootstrap samples.

It fit about equally well in 0 bootstrap samples.

It fit worse or failed to fit in 58 bootstrap samples.

Testing the null hypothesis that the model is correct, Bollen-Stine bootstrap $p=, 259$

Source: Primary Data (2021) 
Table 7 shows bootstrapping analysis modified because it previously did not meet the requirements to continue the research. This bootstrapping analysis shows the results of the Bollen-Stine bootstrap probability $=0.301$, and this value is not significant at a significant level a 0.05 so that this research model is accepted. Based on these results, this research model is still feasible to test all research hypotheses.

Outliers have unique characteristics, look different from other observational data and appear in extreme forms, either univariate or multivariate (Ghozali, 2014). Based on Ferdinand (2006), a multivariate outliers test was identified using the Mahalanobis distance criterion at the level of $p<0.001$. The way to determine the occurrence of multivariate outliers is to use the statistic $d^{2}$ (Mahalanobis Distance) and compare it with the value of $X^{2}$ (Chi-Square) with an error rate of $p<0.001$, df as many as the variables analyzed. In this study, the items used were 28 questions, so the CHIINV $\left(X^{2}\right)$ value obtained from Microsoft Excel 2016 was 56,89229. The following are the results of outlier tests performed on IBM AMOS 22.0 software.

Table 6. Outlier Test Result

\begin{tabular}{ccccc}
\hline Observation number & Mahalanobis d-squared & p1 & $p 2$ \\
\hline 8 & 89,978 &, 000 &, 000 \\
6 & 80,996 &, 000 &, 000 \\
130 & 75,655 &, 000 &, 000 \\
123 & 72,471 &, 000 &, 000 \\
38 & 71,536 &, 000 &, 000 \\
125 & 68,265 &, 000 &, 000 \\
37 & 65,292 &, 000 &, 000 \\
17 & 61,892 &, 000 &, 000 \\
4 & 61,753 &, 000 &, 000 \\
42 & 60,957 &, 000 &, 000 \\
11 & 60,734 &, 000 &, 000 \\
33 & 54,584 &, 002 &, 000 \\
61 & 53,075 &, 003 &, 000 \\
121 & 53,013 &, 003 &, 000 \\
\hline
\end{tabular}

Source: Primary Data (2021)

Based on Table 8, the results of the outlier test found eleven data that were outliers, namely observation data numbers $8,6,130,123,38,125,37,17,4,42$, and 41 , which had Mahalanobis Distance values $\mathrm{d}^{2}>2$ $(56,89229)$. So further analysis excluded the data, and the study analyzed 227 respondents

After screening processes, data were further analyzed by Confirmatory Factor Analysis (CFA) to test the degree to which the measured variable represents a construct. In Structural Equation Modeling, CFA provides information to determine modifications to overcome problems or improve the theory measurement of the proposed model (Hair et al., 2014). Several measures of model fit include Chi-square/Degree of Freedom (CMIN/DF), Tucker-Lewis Index (TLI), Comparative Fit Index (CFI), Goodness of Fit Index (GFI), Standardized Root Mean Residual (SRMR), and Root Mean Square of Error Approximation (RMSEA) (Hair et al., 2014).

Table 7. Model Fit Initial

\begin{tabular}{lccc}
\multicolumn{1}{c}{ Fit Indices } & Cut-Off Value & Results & Description \\
CMIN/DF & $\leq 2.0$ & 1.611 & Fit \\
TLI & $\geq 0.90<1$ & 0.890 & Marginal Fit \\
CFI & $\geq 0.90<1$ & 0.909 & Fit \\
GFI & $\geq 0.90<1$ & 0.863 & Marginal Fit \\
SRMR & $\leq 0.08$ & 0.056 & Fit \\
RMSEA & $\leq 0.08$ & 0.052 & Fit \\
\hline
\end{tabular}

Source: Primary Data (2021)

Figure 1 shows the Confirmatory Factor Analysis for the initial model-the fit index values in Table 9 indicate a good overall model fit. The value of CMIN/ DF has a good value of 1.611, which is below the desired limit value. The SRMR and RMSEA values showed a satisfactory fit with 0.056 and 0.052 as an absolute fit index and fit index measures, respectively. The TLI and GFI results show marginal fit with 0.890 and 0.863 , slightly below the cut-off values, while the CFI value has a good fit index (0.909). To improve the fit of the measurement model, require the procedure to covariate the items using the output of the modified index to improve the results of the model fit. 
Figure 1. CFA Model Initial

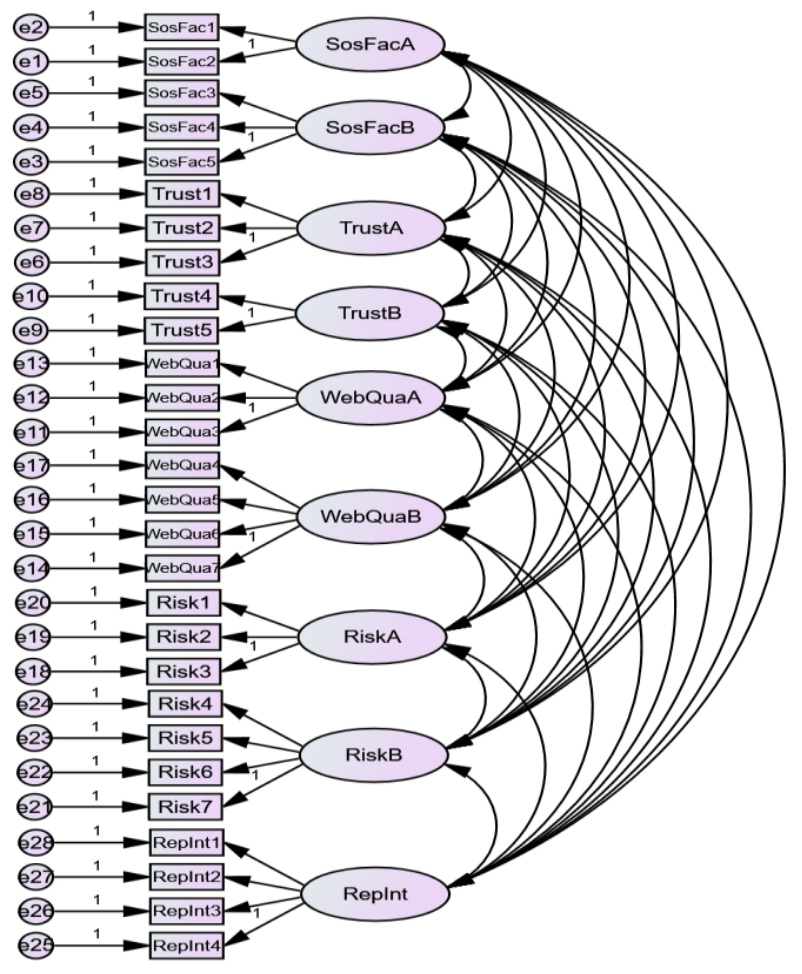

Source: Primary Data (2021)

Table 8. Modification Indicates

\begin{tabular}{lllc} 
& & & M.I. \\
e23 & $<->>$ & e24 & 29,890 \\
e15 & $<->$ & e17 & 5,542 \\
e14 & $<->$ & e15 & 28,146 \\
e13 & <-> & e14 & 5,534 \\
e12 & $<->>$ & $e 17$ & 7,921 \\
e8 & $<->>$ & $e 9$ & 4,774 \\
e6 & $<->>$ & e & 4,415 \\
e2 & $<->$ & e4 & 6,145 \\
\hline
\end{tabular}

Source: Primary Data (2021)

Based on Table 10, the modified Confirmatory Factor Analysis model was shown in Figure 2 below.

Table 9. Model Fit Modified

\begin{tabular}{lccc}
\multicolumn{1}{c}{ Fit Indices } & Cut-Off Value & Results & Description \\
CMIN/DF & $\leq 2.0$ & 1.227 & Fit \\
TLI & $\geq 0.90<1$ & 0.959 & Fit \\
CFI & $\geq 0.90<1$ & 0.967 & Fit \\
GFI & $\geq 0.90<1$ & 0.902 & Fit \\
SRMR & $\leq 0.08$ & 0.048 & Fit \\
RMSEA & $\leq 0.08$ & 0.032 & Fit \\
\hline
\end{tabular}

Source: Primary Data (2021) 
Figure 2. CFA Model Modified

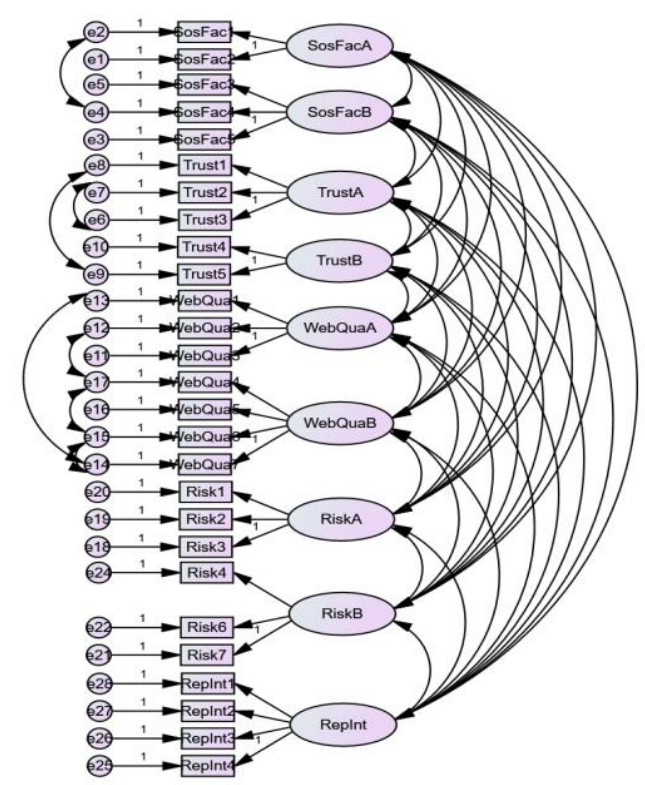

Source: Primary Data (2021)

After some modifications have been made, it can be seen from Table 11 that all values have met the criteria for model fit. The value of $X^{2} / \mathrm{df}$ has a good value of 1.227 . This value increased from 1.661 to 1.227 after modification. The TLI, CFI, and GFI values from the previous $0.890,0.909$, and 0.863 significantly increased to $0.959,0.967$, and 0.902 . Each value shows the desired results for the model fit index. SRMR and RMSEA show satisfactory values with 0.048 and 0.032 , where these results met the goodness of fit index criteria. As a result of the modification, the measurement model has achieved a good model fit for all its index categories. Furthermore, hypothesis testing can be done using a modified model.

\section{SEM Causal Model}

SEM Causal Model analysis was conducted to test all hypotheses. The results of data processing for SEM analysis can be seen in Figure 3 .

Figure 3. SEM Causal Model

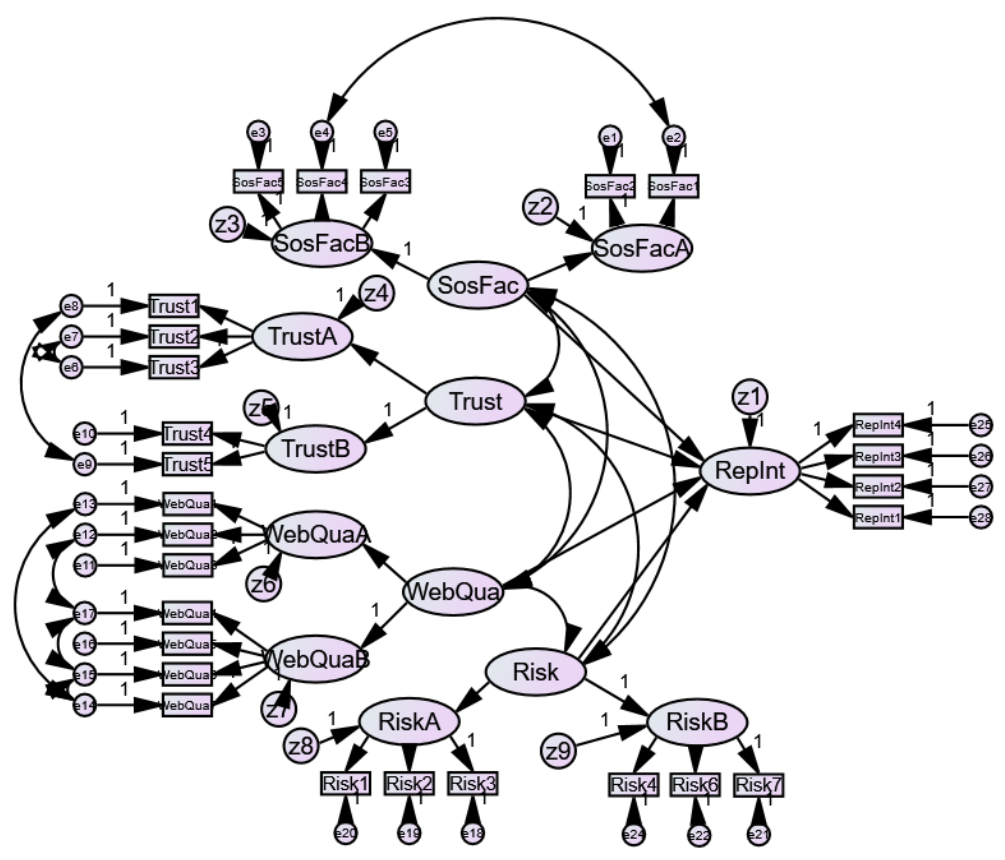

Source: Primary Data (2021) 
Table 10. Model Fit for Causal Model

\begin{tabular}{lccc}
\multicolumn{1}{c}{ Fit Indices } & Cut-Off Value & Results & Description \\
CMIN/DF & $\leq 2.0$ & 1.352 & Fit \\
TLI & $\geq 0.90<1$ & 0.936 & Fit \\
CFI & $\geq 0.90<1$ & 0.946 & Fit \\
GFI & $\geq 0.90<1$ & 0.882 & Marginal Fit \\
SRMR & $\leq 0.08$ & 0.059 & Fit \\
RMSEA & $\leq 0.08$ & 0.039 & Fit \\
\hline
\end{tabular}

Source: Primary Data (2021)

Before testing the hypothesis, another model fit assessment should be carried out to ensure the overall fit of the Causal Model, as presented in Table 12. The value of CMIN/ DF has a good value of 1.352, which is below the desired limit value. The SRMR and RMSEA values showed a satisfactory fit with 0.059 and 0.039 as an absolute fit index and fit index measures, respectively. The TLI and CFI indicate the value of 0.936 and 0.946 , showing the desired model fit of the Causal Model. The GFI results show marginal fit 0.882 , which is slightly below the cut-off values. It is essential to know that the model has a substantial sample and measurement items. Therefore, strict standards on the goodness of fit model are difficult to achieve (Hair et al., 2014). Thus, the researcher assumes that the SEM Causal Model has achieved a good overall model fit.

Table 11. Result of Hypotheses Testing

\begin{tabular}{clllccc}
\hline Hypothesis & & & & C.R. & P & Result \\
\hline$H_{1}$ & Replnt & $<---$ & SosFac & 0,933 & 0,351 & Rejected \\
$H_{2}$ & Replnt & $<---$ & Trust & 1,436 & 0,151 & Rejected \\
$H_{3}$ & Replnt & $<---$ & WebQua & 0,110 & 0,912 & Rejected \\
$H_{4}$ & Replnt & $<---$ & Risk & 2,497 & 0,013 & Accepted \\
\hline
\end{tabular}

Source: Primary Data (2021)

The hypothesis testing criteria refer to the C.R value and $p$-value, where if the C.R value is $>1.96$ and the $p$ value is $<0.05$, then the Independent variable (exogenous) affects the dependent variable (endogenous) (Ghozali, 2014). Based on Table 13, three of the four hypotheses were rejected, and only hypothesis 4 was accepted.

1. $H_{1}$ : Social factors affect the repurchase intention in e-commerce

Based on Table 13, the effect between social factors and repurchase intention has a C.R value of 0.933 and a p-value of 0.351 . The criteria that must be achieved are the C.R value $>1.96$ and the $p$-value < 0.05 , the result indicates that social factor does not significantly impact Repurchase Intention. Therefore, Hypothesis 1 was rejected.

2. $\mathrm{H}_{2}$ : Trust affects the repurchase intention in e-commerce

Based on Table 13, the effect between trust and repurchase intention has a C.R value of 1.436 and a pvalue of 0.151 . The criteria that must be achieved are the $C . R$ value $>1.96$ and the $p$-value $<0.05$, the result indicates that trust has no significant effect on repurchase intention. Therefore, Hypothesis 2 was rejected.

3. $\mathrm{H}_{3}$ : Website quality affects the repurchase intention in e-commerce

Based on Table 13, the effect between website quality and repurchase intention has a C.R value of 0.110 and a $p$-value of 0.912 . The criteria that must be achieved are the C.R value $>1.96$ and the $p$-value $<0.05$, the result indicates that website quality has no significant effect on repurchase intention. Therefore, Hypothesis 3 was rejected.

4. $\mathrm{H}_{4}$ : Perceived risk affects the repurchase intention in e-commerce

Based on Table 13, the effect between perceived risk and repurchase intention has a C.R value of 2.497 and a $p$-value of 0.013 . The criteria that must be achieved are the C.R value $>1.96$ and the $p$-value $<0.05$, the result indicates that perceived risk has a significant impact on repurchase intention. Therefore, Hypothesis 4 was accepted. 


\section{Discussion}

\section{Social Factors do not affect Repurchase Intention.}

The social factor is divided into two aspects: Informational Support and Community Commitment. Informational support can be expressed in advice, recommendations, or experience when using a product. Informational support can help others to make decisions. Meanwhile, community commitment refers to a platform that enables individuals to share their product purchases and consumption experience. Suppose individuals find an online community with the same interests as theirs, and they can appreciate recommendations or opinions valued by other people. In that case, it will create a sense of ownership. However, repurchase intention in e-commerce is not influenced by other people's recommendations or experience in using the product. Respondents tend to have their perceptions of buying a product rather than looking at suggestions from others. Respondents use ecommerce Shopee only to meet their needs or desires, not because they feel as a part of the community that makes them purchases at e-commerce Shopee. In addition, if they are interested in seeing a product, then that opinion will influence their decision to buy a product. The results of this study do not support the results of research from Cetină et al.(2012), Lal (2017), Liang et al. (2011), where social factors influence repurchase intentions in e-commerce.

\section{Trust does not affect Repurchase Intention.}

Trust is defined into two aspects, namely trust toward members and trust toward the community. Trust toward members can determine how members interact and are willing to support each other if a problem arises when someone wants to make a decision. At the same time, trust toward the community is assessed for providers of online e-commerce platforms, particularly its ability to meet the expectations of individuals from the online community. However, hypothesis $\mathrm{H}_{2}$ is rejected. The rejection can be due to acceptable performance shown by e-commerce Shopee, which Shopee e-commerce users considered the performance unsatisfactory. Sometimes other people's comments or suggestions can cause ambiguity, which also applies to comments in the social commerce community. This incident occurs because of the many fake comments or paid reviews by fake customers. The results of this study do not support the results of research from Chen \& Shen (2015), M. J. Kim et al. (2011), Lal (2017), wherein previous studies; was shown that trust influenced repurchase intentions in ecommerce.

\section{Website Quality does not affect Repurchase Intention}

The role of ease of navigation and service quality highly affects the website quality of an e-commerce platform (Lal, 2017). The ability to navigate all features enables users to collect various information easily and finally achieve their goals. The quality of service can be evaluated by how quickly customer care responds to issues experienced by customers when dealing with online shopping. However, hypothesis $\mathrm{H}_{3}$ is rejected. The rejection can happen because the functions provided by e-commerce Shopee to get information accurately and quickly are considered unsatisfactory. This situation causes users to not promptly get information according to the needs or desires of each user. Moreover, the speed level of answering problems by customer care submitted by customers is considered unsatisfactory. The results of this study do not support the results of research from Lal (2017), Liang et al. (2011), Ye et al. (2016), wherein previous studies; it was shown that website quality influenced repurchase intentions in e-commerce.

\section{Perceived Risk does affect Repurchase Intention}

The fourth hypothesis predicts the influence of perceived risk on repurchase intention. The result indicates that hypothesis $\mathrm{H}_{4}$ is accepted. The importance of Financial Risk and Informational Risk in e-commerce refers to individual consumer perceptions of security both for online transactions and financial information or personal information when conducting transactions in e-commerce. Two categories of risk associated with online purchases are financial security (concerns about providing financial information) and non-financial security (related to the disclosure of personal data). From the consumer's point of view, safety control is a quality of service that guarantees "freedom from danger, risk, and doubt" (Ray et al., 2011). Therefore, e-commerce parties need to improve their security so that consumers can think that shopping at e-commerce is very safe. The results of this study support the results of research from Fortes \& Rita (2016); Li et al. (2011); Mandilas et al. (2013), wherein previous studies, it was shown that perceived risk influenced repurchase intentions in e-commerce. 


\section{Conclusion}

The findings in the current study show that three of the four hypotheses are rejected. The social factor, trust, and website quality do not significantly impact customers' repurchase intentions in Shopee e-commerce platform. Only hypothesis $\mathrm{H}_{4}$ was accepted that perceived risk affects repurchase intention in Shopee e-commerce platform. The acceptance shows that although e-commerce has existed for a long time, risk factors become critical factors and always embed in consumer decision-making for shopping online.

The results of the current study have practical implications. The present study results are expected to provide an insight for e-commerce developers, especially Shopee, in determining policies and strategies to develop their e-commerce platform. In particular, developers can improve their e-commerce security services and secure financial and personal information when users conduct online transactions. It is undeniable that the public's perception of risk embeds shopping online. By improving its security services, it is expected that users will be more comfortable and feel safe when shopping online on their website.

This study has several limitations, as follows. First, the respondents in this study, in terms of location, are still very broad because they target the community in Indonesia. Future research may target the respondent's site specifically in a particular area to explain this phenomenon in a specific location.

Second, when evaluating the structural model fit, one indicator does not meet the good fit criteria: the GFI (Goodness of Fit Index) with the marginal fit result. Therefore, in the future other scholars can modify the measurement items that result in better model fit.

Finally, the current study shows that social factors, trust, and website quality do not significantly affect repurchase intentions in e-commerce platforms. Based on these results, other scholars who want to use the same construct can consider or modify measurement items from the same construct to correspond with theoretical support. This research is expected to enrich insights in the studies of e-commerce. The results of this study can be a reference for other scholars who investigate the predictors of purchase intention in the ecommerce platform. Expand the results of this study with the same topic or validate the differences found between other studies with the same issue.

\section{References}

Bateman, P. J., Gray, P. H., \& Butler, B. S. (2011). The impact of community commitment on participation in online communities. Information Systems Research, 22(4), 841-854. https://doi.org/10.1287/isre.1090.0265

Bhatnagar, A., Misra, S., \& Rao, H. R. (2000). On risk, convenience, and Internet shopping behavior: Why some consumers are online shoppers while others are not. Communications of the ACM, 43(11), 98-105.

Cetină, I., Munthiu, M.-C., \& Rădulescu, V. (2012). Psychological and Social Factors that Influence Online Consumer Behavior. Procedia - Social and Behavioral Sciences, 62, 184-188. https://doi.org/10.1016/j.sbspro.2012.09.029

Chang, H. H., \& Chen, S. W. (2008). The impact of online store environment cues on purchase intention: Trust and perceived risk as a mediator. Emerald Insight, 32(6), 818-841. https://doi.org/10.1108/14684520810923953

Chen, J., \& Shen, X. L. (2015). Consumers' decisions in social commerce context: An empirical investigation. Science Direct, 79, 55-64. https://doi.org/10.1016/j.dss.2015.07.012

Consultores, B. (2020). The Importance of Explanatory Research. Online-Tesis. https://online-tesis.com/en/theimportance-of-explanatory-research/

Dominguez, A. (2018). Which Factors Influence Consumer Behaviour? IntegrialMS. https://integriaims.com/en/factors-influencing-consumer-behaviour/

Experian. (2018). Digital Consumers Insights 2018 Convenience, Privacy and the Consumer Fraud Response Cycle. 8. http://www.experian.in/wp-content/uploads/2018/05/IDC-Experian-Digital-Consumer-View-2018V34-INDIA-DIGITAL-MID.pdf

Ferawati, I. (2010). Bootstrap Dalam Structural Equation Modeling ( SEM ) Untuk Mengatasi Asumsi Non-Normal Multivariat.

Ferdinand, A. (2006). Structural Equation Modeling dalam Penelitian Manajemen : Aplikasi Model-Model Rumit dalam Penelitian untuk Tesis Magister dan Disertasi Doktor (3th Editio). Badan Penerbit Universitas 
Diponegoro.

Fortes, N., \& Rita, P. (2016). Privacy concerns and online purchasing behaviour: Towards an integrated model. European Research on Management and Business Economics, 22(3), 167-176. https://doi.org/10.1016/j.iedeen.2016.04.002

Friesner, T. (2014). What is Consumer Behavior? Marketing Teacher. https://www.marketingteacher.com/what-isconsumer-behavior/

Gefan, D., Karahanna, E., \& Straub, D. (2003). Trust and TAM in online shopping: An integrated model. MIS Quarterly, s9-VII(162), 307-321. https://doi.org/10.1093/nq/s9-VII.162.88

George, D., \& Mallery, P. (2016). IBM SPSS Statistics 23 Step by Step (14 Edition). Routledge. https://doi.org/10.4324/9781315545899

Gerbing, D. W., \& Anderson, J. C. (1992). Monte Carlo Evaluations of Goodness of Fit Indices for Structural Equation Models. Sociological Methods \& Research, 21(2), 132-160. https://doi.org/10.1177/0049124192021002002

Ghozali, I. (2014). Model Persamaan Struktural Konsep dan Aplikasi dengan Program Amos 22 Update Bayesian SEM (6th Editio). Badan Penerbit Universitas Diponegoro.

Ghozali, I. (2016). Aplikasi Analisis Multivariate Dengan Program SPSS 23 (Edisi 8) (Edisi VIII). Badan Penerbit Universitas Diponegoro.

Hair, Joe F., Sarstedt, M., Ringle, C. M., \& Mena, J. A. (2012). An Assessment Of The Use Of Partial Least Squares Structural Equation Modeling In Marketing Research. Journal of the Academy of Marketing Science, 40(3), 414-433. https://doi.org/10.1007/s11747-011-0261-6

Hair, Joseph F., Black, W. C., Babin, B. J., \& Anderson, R. E. (2014). Multivariate Data Analysis: Global Edition (7th Editio). Pearson Education Limited. https://doi.org/10.4324/9781351269360

Haryono, S. (2017). Metode SEM untuk penelitian manajemen dengan AMOS 22.00, LISREL 8.80 dan Smart PLS 3.0. Luxima Metro Media, 450.

Kim, D. J., Ferrin, D. L., \& Rao, H. R. (2008). A trust-based consumer decision-making model in electronic commerce: The role of trust, perceived risk, and their antecedents. Decision Support Systems, 44(2), 544564. https://doi.org/10.1016/j.dss.2007.07.001

Kim, M. J., Chung, N., \& Lee, C. K. (2011). The effect of perceived trust on electronic commerce: Shopping online for tourism products and services in South Korea. Tourism Management, 32(2), 256-265. https://doi.org/10.1016/j.tourman.2010.01.011

Lal, P. (2017). Analyzing determinants influencing an individual's intention to use social commerce website. Future Business Journal, 3(1), 70-85. https://doi.org/10.1016/.ffj.2017.02.001

$\mathrm{Li}, \mathrm{H}$., Sarathy, R., \& Xu, H. (2011). The role of affect and cognition on online consumers' decision to disclose personal information to unfamiliar online vendors. Decision Support Systems, 51(3), 434-445. https://doi.org/10.1016/j.dss.2011.01.017

Liang, T. P., Ho, Y. T., Li, Y. W., \& Turban, E. (2011). What drives social commerce: The role of social support and relationship quality. International Journal of Electronic Commerce, 16(2), 69-90. https://doi.org/10.2753/JEC1086-4415160204

Lim, H., \& Dubinsky, A. J. (2004). Consumers' perceptions of e-shopping characteristics: An expectancy-value approach. Journal of Services Marketing, 18(7), 500-513. https://doi.org/10.1108/08876040410561839

Lim, Y. J., Osman, A., Salahuddin, S. N., Romle, A. R., \& Abdullah, S. (2016). Factors Influencing Online Shopping Behavior: The Mediating Role of Purchase Intention. Procedia Economics and Finance, 35(October 2015), 401-410. https://doi.org/10.1016/s2212-5671(16)00050-2

Lu, Y., Zhao, L., \& Wang, B. (2010). From virtual community members to C2C e-commerce buyers: Trust in virtual communities and its effect on consumers' purchase intention. Electronic Commerce Research and Applications, 9(4), 346-360. https://doi.org/10.1016/j.elerap.2009.07.003

Mandilas, A., Karasavvoglou, A., Nikolaidis, M., \& Tsourgiannis, L. (2013). Predicting Consumer's Perceptions in On-line Shopping. Procedia Technology, 8(Haicta), 435-444. https://doi.org/10.1016/j.protcy.2013.11.056

Ray, S., Ow, T., \& Kim, S. S. (2011). Security Assurance: How Online Service Providers Can Influence Security Control Perceptions and Gain Trust. Decision Sciences, 42(2), 391-412. https://doi.org/10.1111/j.15405915.2011.00316.x

Reis, H., Sprecher, S., \& Agnew, C. R. (2013). Commitment, Theories and Typologies. Encyclopedia of Human Relationships. https://doi.org/10.4135/9781412958479.n83

Roscoe, J. T. (1975). Fundamental research statistics for the behavioural sciences (2nd Editio). New York : Holt, Rinehart and Winston. 
Saputro, I. (2019). Ingin Tahu Siapa Pemilik dan CEO Shopee? Infoperbankan. https://www.infoperbankan.com/umum/siapa-ceo-shopee.html

Savolainen, R. (2015). Providing Informational Support in an Online Discussion Group and a Q\&A Site: The Case of Travel Planning. Journal of the Association for Information Science and Technology, 64(March), 450461. https://doi.org/10.1002/asi

Schlosser, A. E., White, T. B., \& Lloyd, S. M. (2006). Converting web site visitors into buyers: How web site investment increases consumer trusting beliefs and online purchase intentions. Journal of Marketing, 70(2), 133-148. https://doi.org/10.1509/jmkg.70.2.133

Tsiakis, T. (2012). Consumers' Issues and Concerns of Perceived Risk of Information Security in Online Framework. The Marketing Strategies. Procedia - Social and Behavioral Sciences, 62, 1265-1270. https://doi.org/10.1016/j.sbspro.2012.09.216

Venkatesh, V., \& Morris, M. G. (2000). Why Don't Men Ever Stop to Ask for Directions? Gender, Social Influence, and Their Role in Technology Acceptance and Usage Behavior. MIS Quarterly, 24(1), 115. https://doi.org/10.2307/3250981

Ye, B. H., Fu, H., \& Law, R. (2016). Use of impact-range performance and asymmetry analyses to improve OTA website quality. Journal of Hospitality and Tourism Management, 26, 9-17. https://doi.org/10.1016/j.jhtm.2015.09.001 